This article has been published in:

Journal of Pragmatics 58 (2013) 145-149

Elsevier

http://doi.org/10.1016/j.pragma.2013.09.014

If you want to quote from this document, please consult the page numbers in the right hand margins.

\title{
Relational work and interpersonal pragmatics
}

\author{
Miriam A. Locher
}

\section{Introduction}

The field of politeness studies has developed considerably within the last decades and today we are faced with discussions on how to best approach this topic theoretically and methodologically, what its scope of investigation should be and how to best combine it with insights from other research traditions within interpersonal pragmatics (for overviews see Locher, 2012, 2013). This has advanced the field but it has also brought about the need to clarify positions in light of insecurities over terminology and research angle/interest. In this brief statement, I will first position my own understanding of the study of the relational side of language - largely developed together with Richard J. Watts and Andreas Langlotz - and react to a number of issues that were raised in connection with the notion of 'relational work' in Spencer-Oatey's contribution to this special issue.

\section{A brief positioning of 'interpersonal pragmatics' and 'relational work'}

In Locher and Graham (2010:2) we offer the term 'interpersonal pragmatics' for research that is interested in studying the interpersonal/relational side of language in use. To illustrate the relational impact on language use we can take the speech act of advising as a starting point: much of the language variation we witness in this speech act is caused by interactants judging whether the content of a particular piece of advice as well as its linguistic rendition (e.g. more direct or indirect forms of language; with or without lexical hedging) conforms to the norms of a particular practice in a particular context and whether such a rendition serves their relational goals (Locher and Limberg, 2012). Next to conveying a particular piece of advice (content/ideational), participants thus also project relational/interpersonal messages in their choice of language rendition. In Locher and 
Watts $(2005,2008)$ we argue that, depending on whether an appropriate or even positively marked form of advice-giving was found, an interactant might be deemed as merely confirming to norms or

even to be polite, well-mannered or refined. In case advice was given in a linguistically (or

otherwise) inadequate way (always with respect to the norms of a given community of practice, see Eckert and McConnell-Ginet, 1992), a person might be considered rude, uncouth, impolite, etc. Crucially, there is no straightforward form-function correlation. Furthermore, these different ways of expressing oneself will have an impact on the relationships between interactants.

These considerations underlie Locher and Watts' (2008:96) notion of 'relational work':

Relational work refers to all aspects of the work invested by individuals in the construction, maintenance, reproduction and transformation of interpersonal relationships among those engaged in social practice. (Locher and Watts, 2009:96)

The concept of relational work highlights relationships as dynamic constructs that emerge through interaction in situated contexts, relative to situated norms. Relational effects can be aggravated, maintained, or enhanced by choosing different language options. While not stated in the definition, there is a straightforward link between relational work and identity

construction (Locher, 2008). Interactants take their face needs, i.e. the projected image they wish to portray in an interaction (independence as well as involvement aspects; Scollon and Scollon, 2001), into account when using language. The work they invest, i.e. the choices they make in interaction in situ, is what we term relational work, and the result of their choices is identity construction. Crucially, 'identity' thus needs to be defined as "intersubjectively rather than individually produced and interactionally emergent rather than assigned in an a priori fashion" (Bucholtz and Hall, 2005:587). Indeed, individuals engage in "the social positioning of self and other" in situated contexts (see Davies and Harré, 1990 for a discussion of 'positioning').

The study of relational work within interpersonal pragmatics has been developed from earlier relational approaches in pragmatics. The relational component of language is wellestablished in linguistic research. For example, Watzlawick et al. (1967) draw attention to the relational side in addition to an ideational side of language, and Halliday (e.g. 1978) has made the interpersonal side one of the pillars (next to ideational and textual) of his work in systemic functional linguistics. The classical politeness literature is also dedicated to interpersonal issues (e.g., Lakoff, 1973; Brown and Levinson, 1978/1987; Leech, 1983). Brown and Levinson (1987) argue that three factors in particular (the power relationship between interactants, the social distance between them and the ranking of a particular imposition) influence linguistic output. Their theory thus fundamentally involves consideration of how interactants interpret their relationships and their standing vis-à-vis each other. In fact, the pragmatic turn, which is at the heart of the early approaches to politeness research (Lakoff, 1973; Brown and Levinson, 1978/1987; Leech, 1983), gives center stage to variation in language in use and the social embeddedness of interaction in 
general. Therefore, scholars like Hymes (1974) highlight the complexity of factors that influence language in use, again also mentioning relational aspects when pointing to the importance of the participants who shape an interaction. Work by the sociologist Goffman (e.g., 1967) complemented this angle and found followers in linguistics (the critical notions of face and facework are adopted and developed from his work), since he deals with how people interact with each other, how they form in-groups and out-groups, and how they position themselves vis-à-vis each other. Since early politeness research developed at a time when theoretical, predictive theory building was thriving, it is also no surprise that these early theories aimed at modeling 'politeness' decisions along a rational path and worked with a rather static interpretation of relationships (see Sifianou, 2010; Watts, 2010 for an overview and criticism of early politeness research), a view that is nowadays often replaced by a more dynamic understanding of the creation of relationships.

Work in politeness research since the 1990s points to several new developments (see Locher, 2012, 2013): The early approaches have been critically assessed and developed, and alternatives have been offered (Fraser, 1990; Meier, 1995; Watts, 1992, among others). An important theoretical discussion developed about whether one should best adopt an etic or emic approach to politeness (Eelen, 2001). Acknowledging that there is a struggle over judgments of politeness phenomena by interactants themselves resulted in a research position loosely termed the 'discursive approach' to politeness (see Linguistic Politeness Research Group, 2011), which is most generally embedded in an interactional sociolinguistics (and often CA) paradigm, which highlights the dynamics of interaction and the situatedness of its enfolding. This new approach - while not unified - argues that the norms of a particular practice are not static but (re)negotiated, and it maintains that it is worthwhile to include the study of the differing first order labels (emic) for relational work instantiations.

In addition to this development, the scope of research interest has been broadened to include the study of linguistic phenomena that are no longer aimed at relationship maintaining or enhancing (potentially resulting in politeness phenomena), but also at conflictual and aggravating behavior. The latter does not only give rise to interest in impoliteness and rudeness (see, Bousfield and Locher, 2008; Culpeper, 2011 for overviews), but also opens the scope to include interest in the relational effects of language use with respect to identity construction more generally (see, Locher, 2008). It is suggested that especially Bucholtz and Hall's (2005) paper on identity construction from a sociocultural linguistic point of view is ideally suited for a combination with the study of relational work.

Finally, as I argue in Locher (2012), there has been a rapprochement of research interests from fields such as social cognition (Langlotz, 2010), the study of identity construction (e.g., Davies and Harré, 1990; Bucholtz and Hall, 2005; Locher, 2008; Spencer-Oatey, 2007) and politeness research. This is both a direct consequence of this broadening of

interest and a result of the fact that all of these fields are concerned with the interpersonal aspect of language use. Having said that, scholars work with alternative terminology when 
conceptualizing and researching interpersonal language use: Spencer-Oatey $(2005,2007)$ speaks of the study of 'rapport management', ${ }^{1}$ Locher and Watts' $(2005,2008)$ propose 'relational work', and Arundale (2010) is developing a 'Face Constituting Theory'. All of these approaches include the study of politeness phenomena but are not restricted to them.

\section{Clarification on a select number of issues}

In Locher (2012) I address questions that have been raised about the discursive approach, which cannot all be reiterated here. However, Spencer-Oatey (2011, in this issue) has made a number of comments in passing that refer to 'relational work' that are worthwhile addressing here. The first block of comments address issues of terminology, while the second are of a primarily methodological nature.

\subsection{Concepts on different planes}

I agree that it is necessary to avoid conflating the terms face, im/politeness and relations. As touched upon above, however, I consider these concepts to be intertwined, yet working on different planes. Following the idea that there is no faceless communication (see Tracy, 1990:221; Scollon and Scollon, 2001:48), I use the Goffmanian (1967) notion of face that claims that interactants wish to present a particular face to others that can be confirmed, maintained or challenged, and is emergent in a particular interaction. For the purpose of this exposé, it is not necessary to further discuss the different aspects of face that have been proposed in the literature; for example whether there are two (independence and involvement, Brown and Levinson, 1987; Scollon and Scollon, 2001; respectability and identity, Spencer-Oatey, 2005) or culturally different (O'Driscoll, 1996) aspects of face. Suffice it to say that it is understood here as a metaphor that allows us to conceive of the fundamental need of interactants to engage in positioning themselves vis-à-vis others (see Locher, 2008). How this face is presented or taken up is what constitutes relational work, i.e. here we are interested in the particular choices interactants make and the dynamics of the unfolding event. As a result, interactants engage in identity construction. While identity is seen as a fundamentally emergent concept, it is acknowledged that interactants draw on complex and multifaceted representations of the self developed in previous interactions, which they negotiate and renegotiate in emergent interaction (for example, the potentially competing concepts of the self as social agent daughter, mother, partner, teacher, scholar, musician, etc.).

\footnotetext{
1 Spencer-Oatey (2007:647) argues that 'relational work' is smaller in scope than 'rapport management'. This view is not shared by the present author, who argues that the two terms are almost synonymous (Locher, 2008). Therefore I also do not agree with Spencer-Oatey's (in this issue) statement that ''relational work' has become too conflated with 'facework' and that it needs to be studied from a much broader perspective." In fact, I argue that relational work is the broader term than facework -- the latter having too often been restricted to the study of mitigation only.
} 
As mentioned above, in Brown and Levinson's (1987) understanding, the social distance and the power difference between interactants, as well as the ranking of the imposition in its cultural context is taken into consideration when interactants choose relational work strategies. In my own understanding, this needs to be complemented with a historical and socio-cognitive dimension (see Locher, 2004; Locher and Watts, 2005, 2008; Langlotz and Locher, 2013). Interactants do not approach other interactants in a particular speech event with a tabula rasa mind. They make analogies to previously experienced interactions and draw on expectations derived from their knowledge of these frames (Tannen, 1993:53). Frames entail knowledge on interactional conventions, roles, and procedures and are acquired in socialization processes; as such they include the expected norms of a particular practice (which may have changed considerably over time; hence the historical aspect mentioned above). Agreeing with Spencer-Oatey (in this issue) that the individual should not be lost to a focus on the emergence of the relational element only, the inclusion of socio-cognitive elements in the understanding of relational work takes care of this desideratum, as it is the individual from which the relational originates and is grounded.

\subsection{Methodological and theoretical framework}

I agree with Spencer-Oatey (in this issue), who calls for recognizing the different strengths and limitations of different approaches and to allow for mixed methodologies. The inclusion of insights from the study of the 'dialectics of relations' (Arundale, 2010), psychology (Spencer-Oatey, 2005) and the recognition that more work needs to be done on the role of emotions in judging the relational aspect of linguistic strategies (Locher and Langlotz, 2008; Langlotz and Locher, 2012, 2013) can only benefit our research endeavor to better understand the complex connection between face, relational work and identity construction. The study of relational work within interpersonal pragmatics does not entail a closed set of methodological decisions. In other words, I see no reason why these different approaches cannot be fruitfully combined

and our earlier publications do not exclude this possibility either. Spencer-Oatey (2011) claims that the 'relational work' approach is too narrow to grasp relational patterns that emerge over time. She gives the example of a workplace team that described lack of communication as a problem in interviews with the researchers, a problem which would not easily emerge by studying recorded data of interaction alone. I would counter that we have always stressed that community norms should be studied over time, and, indeed, if a mixed methodology helps in finding patterns as well as problems perceived by the interactants themselves, there is surely nothing wrong with that. ${ }^{2}$ From a methodological

\footnotetext{
2 I assume that our insistence on keeping the study of first order concepts distinct from second order concepts (Locher and Watts, 2005, 2008) has led to the impression that we are against a mixed methodology. While I still subscribe to the idea that it is the interactants themselves who are the primary people involved in making judgements about the relational aspect of utterances, one of the primary point of these papers was to raise awareness about the fact that we are dealing with first order notions when we speak of politeness, impoliteness, rudeness, or any similar such lexemes. Depending on the scholar's research interest one can
} 
perspective, it remains important to clearly state whether one is studying meta-comments on relational work derived from interactants in interviews, or that one is working with a theoretical, top-down approach, or that one is attempting to study first order concepts as they emerge in interaction, or indeed a combination of these options. As in any research endeavor, scholars have to be clear about what they are studying: Is the point of interest politeness and impoliteness as first order notions, the study of identity construction and relationship negotiation in situ, the establishing of community of practice norms for relational conduct over time, the developing of a theoretical framework to explain the relational component of language in use, etc.? Depending on the chosen research focus, the scholars then clarify what methodologies they are drawing on to answer their research questions in the best possible way.

\section{Concluding remarks}

My own research path over the last decade has led me to widen my interest, departing from focusing on politeness to zooming in on the relational aspect of communication more holistically. This shift went hand in hand with combining a first order with a second order approach. While I am still interested in the study of politeness, impoliteness, etc., I attempt to study and use these terms as first order terms (the differentiation between impolite, non-polite, polite and over-polite proposed in Locher and Watts (2005) are examples of such first order terms and there are many more with much semantic overlap among them). For the technical description of relational work strategies, I refer to the concepts of faceenhancing, face-maintaining and face-aggravating behavior, which are terms not commonly employed by non-linguists. This approach allows me to further explore the interface of 'face', 'relational work' and 'identity construction' in their connectedness and difference, while recognizing that much is to be gained by drawing on disciplines that have traditionally dealt with these notions and disciplines that share an interest in the relational aspect of communication.

\section{References}

Arundale, Robert, 2010. Relating. In: Locher, M.A., Graham, S.L. (Eds.), Interpersonal Pragmatics. Mouton, Berlin, pp. 137-167.

Bousfield, Derek, Locher, Miriam A. (Eds.), 2008. Impoliteness in Language. Studies on its Interplay with Power in Theory and Practice. Mouton de Gruyter, Berlin.

Brown, Penelope, Levinson, Stephen C., 1978. Universals in language usage: politeness phenomena. In: Goody, E.N. (Ed.), Questions and Politeness. Cambridge University Press, Cambridge, pp. 56-289.

Brown, Penelope, Levinson, Stephen C., 1987. Politeness. Some Universals in Language Usage.

Cambridge University Press, Cambridge.

combine first order with second order notions in a meaningful way and mix methodologies (see Locher, 2012 for further pointers). 
Bucholtz, Mary, Hall, Kira, 2005. Identity and interaction: a sociocultural linguistic approach. Discourse Studies 7 (4-5), 585-614.

Culpeper, Jonathan, 2011. Impoliteness: Using Language to Cause Offence. Cambridge University Press, Cambridge.

Davies, Bronwyn, Harré, Rom, 1990. Positioning: the discursive production of selves. Journal of the Theory of Social Behaviour 20, 43-65.

Eckert, Penelope, McConnell-Ginet, Sally, 1992. Communities of practice: where language, gender, and power all live. In: Hall, K., Bucholtz, M., Moonwoman, B. (Eds.), Locating Power. Proceedings of the Second Berkeley Women and Language Conference. Women and Language Group, Berkeley, pp. 89-99.

Eelen, Gino, 2001. A Critique of Politeness Theories. St. Jerome Publishing, Manchester.

Fraser, Bruce, 1990. Perspectives on politeness. Journal of Pragmatics 14 (2), 219-236.

Goffman, Ervin (Ed.), 1967. Interaction Ritual: Essays on Face-to-face Behavior. Anchor Books, Garden City, NY.

Halliday, Michael A.K., 1978. Language as a Social Semiotic: The Social Interpretation of Language and Meaning. Edward Arnold, London.

Hymes, Dell, 1974. Foundations in Sociolinguistics: An Ethnographic Approach. University of Pennsylvania Press, Philadelphia.

Lakoff, Robin Tolmach, 1973. The logic of politeness, or minding your p's and q's. Chicago Linguistics Society 9, 292-305.

Langlotz, Andreas, 2010. Social cognition. In: Locher, M.A., Graham, S.L. (Eds.), Interpersonal Pragmatics. Mouton, Berlin, pp. 167-202.

Langlotz, Andreas, Locher, Miriam A., 2012. Ways of communicating emotional stance in online disagreements. Journal of Pragmatics 44 (12), 1591-1606.

Langlotz, Andreas, Locher, Miriam A., 2013. The role of emotions in relational work. Journal of Pragmatics 58, 87-107.

Leech, Geoffrey N., 1983. Principles of Pragmatics. Longman, New York.

Linguistic Politeness Research Group (Eds.), 2011. Discursive Approaches to Politeness. Walter de Gruyter, Berlin.

Locher, Miriam A., 2004. Power and Politeness in Action: Disagreements in Oral Communication. Mouton de Gruyter, Berlin.

Locher, Miriam A., 2008. Relational work, politeness and identity construction. In: Antos, G., Ventola, E., Weber, T. (Eds.), Handbooks of Applied Linguistics. Vol. 2: Interpersonal Communication. Mouton de Gruyter, Berlin, pp. 509-540.

Locher, Miriam A., 2012. Politeness research from past to future, with a special focus on the discursive approach. In: Amaya, Lucía Fernandez, Hernandez Lopez, Maria de la O., Moron, Reyes Gomez, Cruz, Manuel Padilla, Borrero, Manuel Mejias, Barranca, Mariana Relinque (Eds.), New Perspectives on (Im)Politeness and Interpersonal Communication. Cambridge Scholars Publishing, Cambridge, pp. 1-22.

Locher, Miriam A., 2013. Politeness. In: Chapelle, Carol E. (Ed.), The Encyclopedia of Applied Linguistics. Wiley-Blackwell, Oxford, UK.

Locher, Miriam A., Graham, Sage L., 2010. Introduction to interpersonal pragmatics. In: Locher, M.A., Graham, S.L. (Eds.), Interpersonal Pragmatics. Mouton, Berlin, pp. 1-13.

Locher, Miriam A., Langlotz, Andreas, 2008. Relational work: at the intersection of cognition, interaction and emotion. Bulletin Suisse de Linguistique Appliquée (VALS-ASLA) 88, 165-191. 
Locher, Miriam A., Limberg, Holger, 2012. Introduction to advice in discourse. In: Limberg, H., Locher, M.A. (Eds.), Advice in Discourse. John Benjamins, Amsterdam, pp. 1-27.

Locher, Miriam A., Watts, Richard J., 2005. Politeness theory and relational work. Journal of Politeness Research 1 (1), 9-33.

Locher, M.A., Watts, Richard J., 2008. Relational work and impoliteness: negotiating norms of linguistic behaviour. In: Bousfield, D., Locher, M.A. (Eds.), Impoliteness in Language: Studies on its Interplay with Power in Theory and Practice. Mouton de Gruyter, Berlin, pp. 77-99.

Meier, Ardith J., 1995. Passages of politeness. Journal of Pragmatics 24 (4), 381-392.

O'Driscoll, Jim, 1996. About face: a defence and elaboration of universal dualism. Journal of Pragmatics 25 (1), 1-32.

Scollon, Ron, Scollon, Suzanne W., 2001. Intercultural Communication: A Discourse Approach. Blackwell, Oxford.

Sifianou, Maria, 2010. Linguistic politeness: laying the foundations. In: Locher, M.A., Graham, S.L. (Eds.), Interpersonal Pragmatics. Mouton, Berlin, pp. 17-41.

Spencer-Oatey, Helen, 2005. (Im)politeness, face and perceptions of rapport: unpackaging their bases and interrelationships. Journal of Politeness Research 1 (1), 95-119.

Spencer-Oatey, Helen, 2007. Theories of identity and the analysis of face. Journal of Pragmatics 39, 639-656.

Spencer-Oatey, Helen, 2011. Conceptualising 'the relational' in pragmatics: insights from metapragmatic emotion and (im)politeness comments. Journal of Pragmatics 43, 3565-3578.

Tannen, Deborah, 1993. What's in a frame? Surface evidence for underlying expectations. In: Tannen, D. (Ed.), Framing in Discourse. Oxford University Press, Oxford, pp. 14-56.

Tracy, Karen, 1990. The many faces of facework. In: Giles, H., Robinson, P. (Eds.), Handbook of Language and Social Psychology. Wiley, Chichester, pp. 209-226.

Watts, Richard J., 1992. Linguistic politeness and politic verbal behaviour: reconsidering claims for universality. In: Watts, R.J., Ide, S., Ehlich, K. (Eds.), Politeness in Language: Studies in its History, Theory and Practice. Mouton de Gruyter, Berlin, pp. 43-69.

Watts, Richard J., 2010. Linguistic politeness theory and its aftermath: recent research trails. In: Locher, M.A., Graham, S.L. (Eds.), Interpersonal Pragmatics. Mouton, Berlin, pp. 43-70.

Watzlawick, Paul, Beavin, Janet Helmick, Jackson, Don D., 1967. Pragmatics of Human

Communication. A Study of Interactional Patterns, Pathologies and Paradoxes. Norton. 